\title{
Determination and Evaluation of the Cooling Load of a Building Made by Different Local Material of Construction
}

\author{
AMADOU OUMAROU Fati ${ }^{1 *}$, Ramchandra BHANDARI ${ }^{2}$, MAMADOU Lewamy $^{3}, \mathrm{KY}$ \\ Thierry S.M ${ }^{1}$, OUEDRAOGO Souleymane ${ }^{1}$, Rabani Adamou ${ }^{3}$, COMPAORÉ Abdoulaye $^{1}$, \\ BATHIEBO Dieudonné Joseph ${ }^{1}$ \\ ${ }^{1}$ Joseph KI-Zerbo University, UFR/SEA, Laboratory of Renewable Thermal Energies \\ Ouagadougou, Burkina Faso. \\ ${ }^{2}$ Institute for Technology and Resources Management in the Tropics and Subtropics: ITT \\ Cologne, Germany. \\ ${ }^{3}$ Abdou Moumouni University, Faculty of Science and Technology, Department of \\ Chemistry, Niamey, Niger.
}

\#corresponding author.

Type of Review: Peer Reviewed.

DOl: http://dx.doi.org/10.21013/jas.v15.n5.p1

\section{How to cite this paper:}

Fati et al. (2020). Determination and Evaluation of the Cooling Load of a Building Made by Different Local Material of Construction. IRA International Journal of Applied Sciences (ISSN 24554499), 15(1), 1-14. doi:http://dx.doi.org/10.21013/jas.v15.n5.p1

(C) Institute of Research Advances.

(c) Br-No

This work is licensed under a Creative Commons Attribution-Non Commercial 4.0 International License subject to a proper citation to the publication source of the work.

Disclaimer: The scholarly papers as reviewed and published by the Institute of Research Advances (IRA) are the views and opinions of their respective authors and are not the views or opinions of the IRA. The IRA disclaims of any harm or loss caused due to the published content to any party.

Institute of Research Advances is an institutional publisher member of Publishers International Linking Association Inc. (PILA-CrossRef), USA. The institute is an institutional signatory to the Budapest Open Access Initiative. Hungary advocating the open-access of scientific and scholarly knowledge. The Institute is a registered content provider under Open Access Initiative Protocol for Metadata Harvesting (OAl-PMH).

The journal is indexed \& included in CAS Source Index of Chemical Abstracts Service of American Chemical Society (USA), Index Copernicus (IC Value 85.27), WorldCat Discovery Service (USA), CrossRef Metadata Search (USA), WorldCat (USA), OCLC (USA), Open J-Gate (India), EZB (Germany) Scilit (Switzerland), Airiti (China), Bielefeld Academic Search Engine (BASE) of Bielefeld University, Germany, PKP Index of Simon Fraser University, Canada. 


\begin{abstract}
This paper aims to describe a passive approach to reduce the energy demand for an existing building and can be made through an improvement of the design of the thermal envelope. The essential article goal is to simulate thermal construction responses in dependence on changing different materials of the construction of the building and also with less energy usage to design a more effective cooling system. In this approach, we simulate the building with different materials: three local materials (compressed earth, lateritic, and raw material) and one modern (Hollow cement) used in Burkina Faso and an energy analysis of the building has been carried out. The numerical optimization of the building design has been performed dynamically for these four materials using the COMSOL multiphysics simulation tool. The model treated is determining the internal temperature and cooling demand concerning a tertiary building in Burkina Faso like a classroom, which is located in a hot and dry climate to improve the indoor quality of the classroom knowing the importance of the thermal comfort in the room for socio-economic performance efficiency and well-being. The analysis result of these four materials shows that energy can be saved if we use local materials instead of the modern one because around $4 K W$ of energy can be saving with local materials. The use of local materials in the building design can be an option for reducing the heat transfer into the room and at the same time the energy consumption.
\end{abstract}

Keywords: thermal comfort, less energy usage, local materials, cooling loads, indoor quality, energy performance.

\title{
Introduction
}

The twenty-first century is rapidly becoming the perfect energy storm, modern society is faced with volatile energy prices and growing environmental concerns as well as energy supply and security issues. Indeed, energy is defined as the Alma, the lifeblood and also the continuously driven power of any society wishing to develop. Currently, most of human energy consumption is based on fossil energy resources. The increasing energy demands in the building sector are considered main issue and have resulted both in the energy shortage and also negative environmental impacts such as climate change and global warming. This demand is always increasing due to the climate, the high-rise level, and also the need for thermal comfort. Nowadays, the fossil fuels satisfy around $80 \%$ of the total energy needs, and their direct impact on the climate is alarming because they are responsible for the emissions of large amounts of greenhouse gases (GHGs) such as carbon dioxide. The IPCC states that the increase in the concentration of GHGs in the atmosphere is likely to cause significant climate change such as an increase in global temperatures, rising sea levels, and intensification of extreme weather events through depletion of the ozone layer[1]. In response to climate change and global warming, one of the greatest threats facing the planet, it was then agreed that a lot of conventions have been set up. The objectives of all these initiatives are to reduce the $\mathrm{CO} 2$ emissions in the Ozone Layer [2]. Actions need to be taken especially in the building sector which because is a highlight to be significantly contributing to the increased greenhouse gas emission in worldwide energy consumption. The building sector is the most energy-consuming because it alone accounts for $40 \%$ of total energy worldwide and is responsible for 30\% GHG emissions [3].

\subsection{Background on the energy in building}

Since ancient times man has always sought to protect himself from the dangers that surround him and the aggressions of the environment, in particular, the climate. The main reason for designing buildings is usually to shelter occupants and achieve thermal comfort in the occupied space [4]. Its protection goal has evolved and varied according to time, need and environment. This is how man has always tried to acclimatize with his environment, making the act of building one of his fundamental occupations: "the man who builds above all else, to shelter and protect himself evolution of cultural, economic, constructive and energetic conditions, the essential objective of any constructive activity is always and again the protection of the man against the climatic elements, the excessive sunshine, the extreme temperatures, the precipitations and the wind" [1]. The building sector is becoming a trend for future construction, enabling environmental sustainability, energy security, and also reliability [4]. Building the environment plays a 
vital role in the inhabitants' productivity, morale, and satisfaction. Indeed, man spends most of his time in enclosed spaces such as homes, cinema, schools, and offices. An average, more than $50 \%$ of a building's energy is used by the heating, ventilation, and air conditioning (HVAC) system[5]. In the hottest countries such as Niger and Burkina Faso, this can be as high as 70\%[6][7]. Indeed, the main objective of using these HVAC systems is to improve the thermal comfort in the building. Nowadays, people spend most of their time in enclosed spaces such as Building, classroom Houses[3][8], and poor comfort in buildings increases the chances of sick building syndrome, such as absenteeism and cognitive degradation [9]. Thermal comfort modeling in the building is crucial for economic performance, operation, and optimization. Thus, it is important to create a healthy and comfortable indoor space, while at the same time minimizing building energy use. Knowing the adverse environmental impacts and energy challenges facing the world in general, and in order to reduce the extensive use of energy, the building sector is positioning as a key sector to meet our national commitments on these themes. A key step towards this goal is using local materials to improve the building indoor quality, architectural design and renewable energies. While more than $90 \%$ of the people spend most of their time inside buildings. Building environment plays vital role for inhabitants' productivity, morale and satisfaction. Therefore, being competitive economically, and meeting increasing environmental standards in the building industry is yet an open challenge for researchers[4].

In Burkina Faso, these last two decades, we have witnessed multiple and intensive projects of building that consume too much energy. This high consumption in the building sector is caused, among other things, by the fact that buildings are unfortunately not subject to any energy regulatory, lack of energy considerations in the design and management of buildings, lack of energy regulations in the building sector and also there are no requirements in terms of thermal and energy efficiency [10]. This lack in the buildings sector leads to uncomfortable and energy-hungry buildings and extensive use of energy to improve the indoor conditions for the habitant. Our objective is to determine the cooling loads in the building by using local materials for energy efficiency in building and also the enhancement of the ecology and the protection of the environment.

Currently, the energy and environmental concerns are marked by two phenomena, the consequences of which give rise to real questions of sustainability: this is partly due to the increase in pollution and, secondly, to de sharp decline in exhaustible energy resources (fossil fuel-based). Since, the last two decades, due to the issues of environmental, ecological, energy conservation and sustainable development have become an essential part of the building industry. The building sector is becoming a trend for future construction, enabling environmental sustainability, energy security, and also reliability[11]. Building the environment plays a vital role in the inhabitants' productivity, morale, and satisfaction. In this case, many efforts have been made to reduce the share of $\mathrm{CO}_{2}$ emissions by building energy savings and efficient techniques. To achieve energy saving in the building sector, it is fundamental to predict the energy flow, to see where energy saving will be most effective and which allows us to offer high comfort. One of the strategies is the Building Energy Resource Management (BERM) which can help to meet the critical objectives of improving environmental quality and energy saving in building operation. To do this; inhabitants need to cut their energy bills and improve their quality of living comfort, and also a requirement on the appropriate design and the implementation of adaptable control schemes [4][12].

The valorization of local materials used in the building sector and energy performance constitute nowadays a very important field of research capital worldwide [13]. Researchers and scientists are working on energy modeling and control to develop strategies that will have an impact on the reduction of energy consumption in buildings. There is only a limited amount of research literature on energy-efficient in building design in hot and dry climates. We will try to give an overview of the previous study and to 
predict the effect of different thermal models on the energy performance in the building. Higgs [8] reported another study in 1994 which investigated the effects of self-shading on the cooling load and energy consumption. The result of his study showed that self-shading reduced both the peak cooling load and energy consumption of south and west-facing apartments by more than $15 \%$. Therefore, the study made by Mohamed. L and al [14], have studied the influence of thermophysical properties of walls on the energy-saving state that, when we add pomace olive on the clay, it can improve the energy performance by reducing the thermal conductivity from $0.65 \mathrm{~W} \cdot \mathrm{m}^{-1} \mathrm{~K}^{-1}$ to $0.29 \mathrm{~W} \cdot \mathrm{m}^{-1} \mathrm{~K}^{-1}$. The numerical analysis of Toguyeni and al [15]on the impact of local roofing materials on the cooling need in Burkina Faso. His work shows that; the mixture clay-straw can reduce the cooling loads by about $8 \%$ compared to the pure clay. Madi Kaboré and al have determined a numerical study on the influence of the rood performance on the cooling loads as passive cooling to improve thermal comfort. Within this work, we will investigate the advantages and the potential of using local building materials to improve energy performance and the energy efficiency in buildings under tropical climatic conditions.

\subsection{Thermal comfort in buildings}

The thermal comfort of an occupant is mainly defined as that sensation of mind that expresses satisfaction to the thermal environment and it is governed by the heat transfer between the human body and its environment. The most important parameters that influence the human comfort are cited in the figure 1 below.
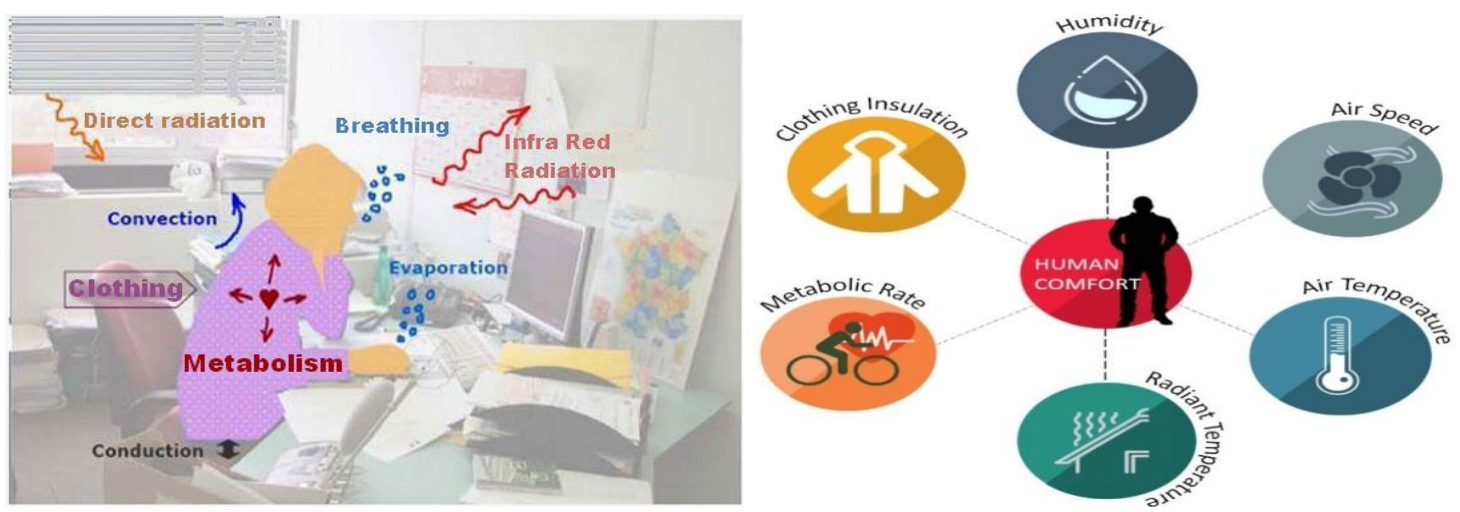

Figure 1: Interaction between human and its environment [16]

It is also defined as the state of feeling of general well-being and can be perceived as the comfort of human beings under given room conditions. The body is a thermal machine that permanently regulates body temperature around $37^{\circ} \mathrm{C}$. Numbers of parameters that integrates both human perception and physical assessment. The epidermal surface exchange with its environment by convection, conduction, radiation, and change of phase (the latent heat of evaporation required and partially ceded by the body itself). The thermal comfort is a function of multiple parameters as varied as activity, metabolism, clothing, or airspeed. Of course, the thermo-aeraulic conditions and the moisture content of its environment are taken into account in heat transfer mechanisms: dry air temperature, average radiant temperature, air velocity, and hygrometry. Otherwise, psychological and sociological aspects come into play in the subjective feeling of comfort thermal [17]. Then, the specification about thermal comfort objectives that a building should achieve a prerequisite for its design which must be explicitly included as an integral part of the building and need to be quantitatively defined through reliable and explicit methods for assessing the thermal comfort performance of a building [18]. 
To define the variety of thermal comfort, many methods are available in literature such as Fanger's comfort model (also called static model), the European adaptive model, the American adaptive comfort model, and the Givoni's Building Bioclimatic Chart is shown in figure 2.

We need to try to get into this zone

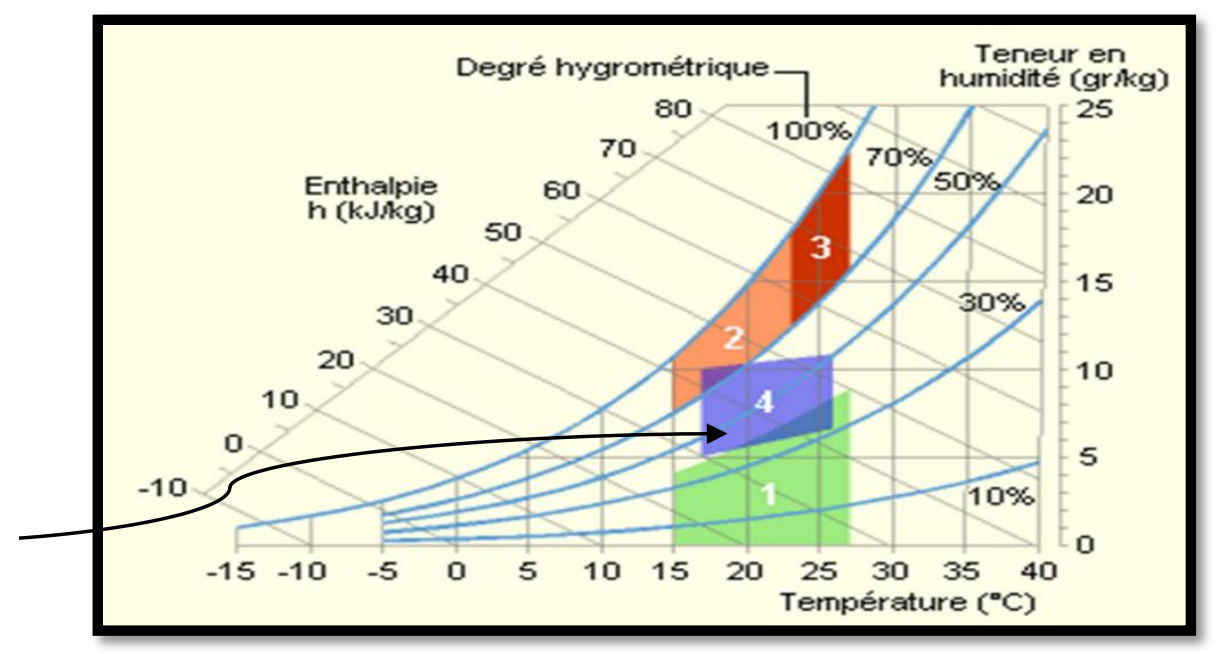

Figure 2: Givoni’s Building Bioclimatic Chart

The analytic model of thermal comfort is based on the Fanger's model also called the static model. In 1972, Fanger [19] has developed the PMV (Predicted Mean Vote) and PPD (Predicted Percentage of Dissatisfied) ISO 7730 [20][21] based on the equation of heat balance of the body with is given by the following equation to evaluate the thermal comfort:

$$
\begin{aligned}
& C T=L=(M-W)-\left(E_{\text {vap }}+R_{\text {esp }}+K+C+R\right)=m C \frac{d T}{d t} \\
& P M V=[0,303 \cdot \exp (-0036 M)+0,028] . L \\
& P P D=100-95 \exp \left[-\left(0,03353 \cdot P M V^{4}+0,2179 P M V^{2}\right)\right]
\end{aligned}
$$

The equilibrium is obtained when PMV $=0 \rightarrow \mathrm{PPD}=100 \%$

In this figure 3 below, the first one (a) is the curve of the equation PPD $=(P M V)$ which is the [Eq. 3] and the second figure (b) is the feeling based on the PMV index of a sensation of comfort. 

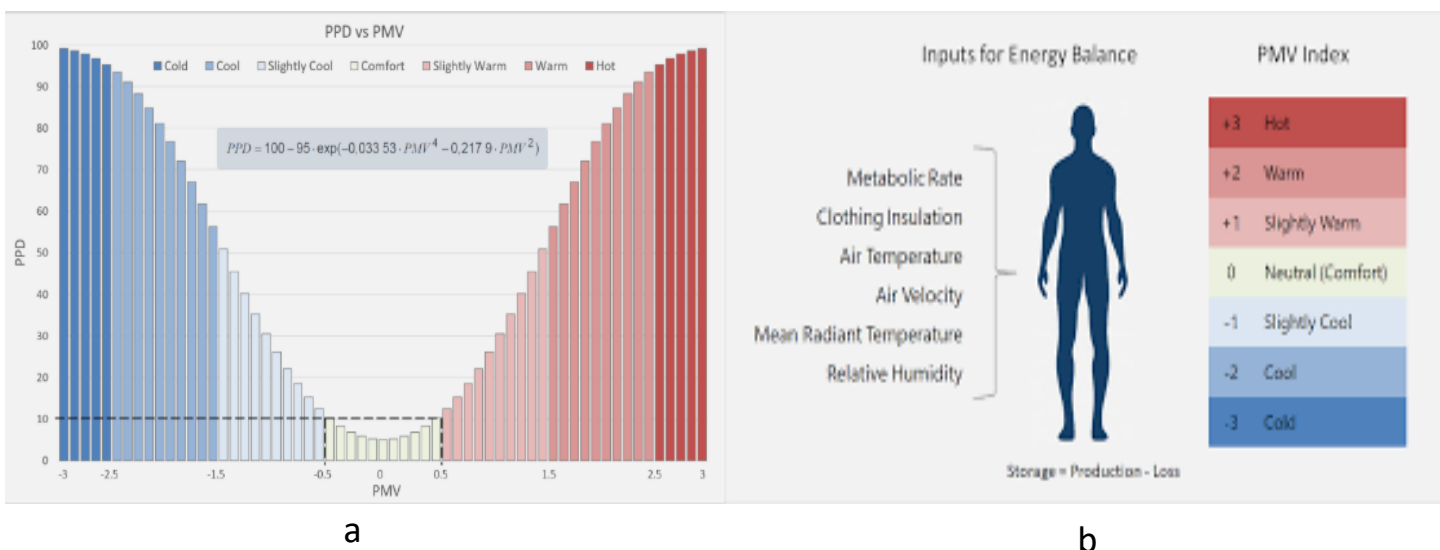

Figure 3: Approach of Fanger: PMV and PPD [19]

\section{Materials and methods}

The model chooses for the simulation is assimilated into a single room to simplify the complexity of the simulation. During the study procedure, we consider habitats whose walls are respectively made of the four materials previously cited such as compressed earth block, lateritic earth blocks raw earth, and hollow cement block. The modeling of the cooling loads is given by taking into account the case study of the weather conditions of April and the time for the evaluation of the cooling loads is $12 \mathrm{~h}$ (noon). The premise has the followings dimensions: $\mathrm{S}=15 \mathrm{~m} * 6.666 \mathrm{~m} ; \mathrm{H}=4 \mathrm{~m}$ and the thickness of the walls are $20 \mathrm{~cm}$. The roof of the house is considered like being slab with also $20 \mathrm{~cm}$ of thickness. To simulate our building, we then need the properties of those four materials mostly use in our countries Niger and Burkina Faso. The dynamical study is already done in our previous work[22] taking into account the simplification hypothesis.

The thermo-physical properties are considered as constant and are given in Table $\mathbf{1}$ below:

Table 1: Thermophysical properties of the most used local materials

\begin{tabular}{|c|c|c|c|c|}
\hline & Conductivity & Specific heat & & Density \\
\hline Raw earth / Adobe & 0.5 & 1305 & & 1060 \\
\hline Compressed earth block / BTC & 1.05 & 1500 & & 1800 \\
\hline Lateritic carved block / BLT & 0.556 & 1075 & & 1310 \\
\hline Hollow cement block / Parpaing & 0.785 & 1050 & & 1275 \\
\hline
\end{tabular}

The model of the building in Comsol software after the first simulation is as follows in figure 4. 


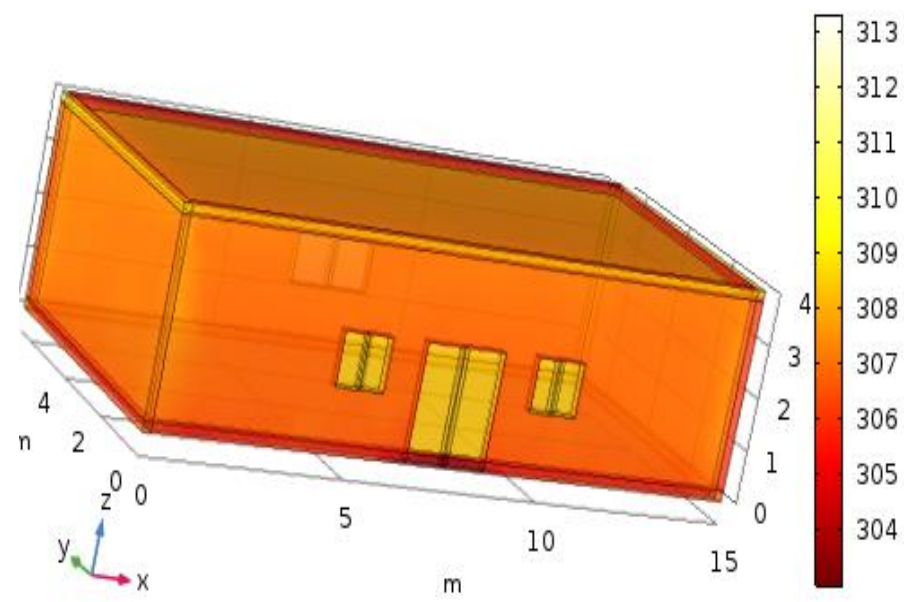

Figure 4: The model of the design of the building

The main program's ability of Transient heat transfer is based on numerical solving of second order Partial Differential Equation (PDE) by finite element method (FEM). The usage of this program for similar problems, namely transient heat transfer can be found in [23]. The heat transfer is described by conduction, convection, and radiation with the heat transfer module and laminar flow module of air circulation.

\subsection{Determination of the cooling loads for a typical room in Ouagadougou}

The assessment of the heat balance is based on the estimation of the external and internal gains during the hottest month called the base month. Table 2 gives us the different base months for some sample cities in Africa[24].

Table 2: Base month (hottest month)

\begin{tabular}{|c|c|c|c|}
\hline Climate zones & Countries & Reference cities & Base month \\
\hline Humid tropical climate & Côte d'Ivoire & Abidjan & February \\
\hline Dry tropical climate & Cameroon & Garoua & March \\
\hline Desert tropical climate & Burkina Faso & Ouagadougou & April \\
\hline
\end{tabular}

To do this study, first, we have developed a numerical model to study the thermal behavior of a classroom-oriented to the North direction in the case of study Ouagadougou. In this model, a typical base case building is selected for simulation analysis to examine the impact of the local materials on thermal comfort and energy performance. In order to determine the cooling load and the energy saving, first, we simulate the model in Comsol software and then we calculate all the following parameters.

Rayleigh, $R_{a}=g \beta \frac{H^{3}}{\alpha \eta} \Delta T=1,23.10^{12}$

(Eq.4),

Nusselt, $N u=0,13 \cdot R a^{0,33}=1,27 \cdot 10^{3} \quad$ (Eq.5);

$h_{e}=5,7+3,8 \mathrm{~V}=15,2$ where $\mathrm{V}=2.5$ 
The coefficient of convection and the global coefficient of transmission

$$
K=\frac{1}{\left(\frac{1}{h_{e}}+\frac{e}{\lambda_{B T C}}+\frac{1}{h_{i}}\right)}=2,1
$$

The value of the coefficient of convection will help us to know which equation to use.

The main equation of heat transfer is in the building is

$\nabla . q+\rho C_{P} u . \nabla T+\rho C_{P} \frac{\partial T}{\partial t}=Q$

Where,

$$
q=-\lambda \nabla T
$$

$\mathrm{T}$ is the room temperature, $\rho$ density, $\mathrm{Cp}$ heat capacity, $\mathrm{u}$ speed, $\mathrm{t}$ time, $\mathrm{Q}$ heat source. The first part of this equation refers to HT by conduction, the second to convection process, and the third part to heat accumulation in the mass of a specific domain.

We obtain for each of the walls, the roof and the ground an equation of the type below:

$$
\rho C_{P} \frac{\partial T}{\partial t}+\nabla \cdot q=Q
$$

We make a thermal balance at all times of the volume of air in the enclosure taking into account all the flows transmitted by convection and by radiation, assuming that this volume is isothermal.

$$
m C_{P} \frac{d T}{d t}+\int_{S}(n . q) d S=\int_{V} Q d V
$$

We suppose a well-mixed fluid domain so that the temperature of internal air is calculated with (Eq.11). In the proposed model there is no internal heat production. The different heat flows on the external and internal borders:

Convective heat flux on external boundaries and boundaries related to internal air is represented by Neumann boundary condition

$$
q=h_{i}\left(T_{p}-T_{\text {int }}\right) o n \partial \Omega_{\text {int }}
$$

Where, $q$ means heat flux, $h$ heat transfer coefficient (HTC), $\mathrm{T}$ boundary temperature, and $\mathrm{T}_{\text {inf }}$ external temperature.

$$
q=h_{e}\left(T_{e}-T_{P}\right) \text { ond } \Omega_{\mathrm{ext}} \quad \text { (Eq.13)[25] }
$$

A condition that describes heat transfer by radiation is applied on boundaries with internal air was active also second boundary equation, which describes Heat Transfer by radiation 


$$
q=\varepsilon \sigma\left(T_{P}^{4}-T_{a m b}^{4}\right) o n \partial \Omega_{\mathrm{ext}}
$$

Where, $\varepsilon$ means emissivity, $\sigma$ Stefan Boltzmann constant, $\mathrm{T}_{\mathrm{amb}}$ ambient temperature, $\mathrm{T}_{\mathrm{p}}$ boundary temperature. These equations can easily help us to find the meshing of the model in COMSOL Multiphysics software.

\section{Result and discussions}

As a preliminary result of our study, we have first designed a soft MATLAB R2018a program to determine the heat flux that arrives on the different sides of the wall. The building energy analysis is performed by using the COMSOL multiphysics and also MATLAB software. To solve the equations of the problem studied, we have selected the nodal method. To do the modeling on COMSOL software, we first made a study of the variation of the global solar radiation flux which arrives on the different faces of the wall of our room with MATLAB software and based on the geographical position of Ouagadougou. We have determined the evaluation of heat flow coming from the sun for each side of the building on the $15^{\text {th }}$ of April the hottest month of the year in Burkina Faso. This study shows the evolution of the global horizontal solar flux density which can help us see the amount of incidence solar radiation that comes to the external faces of the building regardless of the nature of the material used and also how they will affect the internal average temperature.

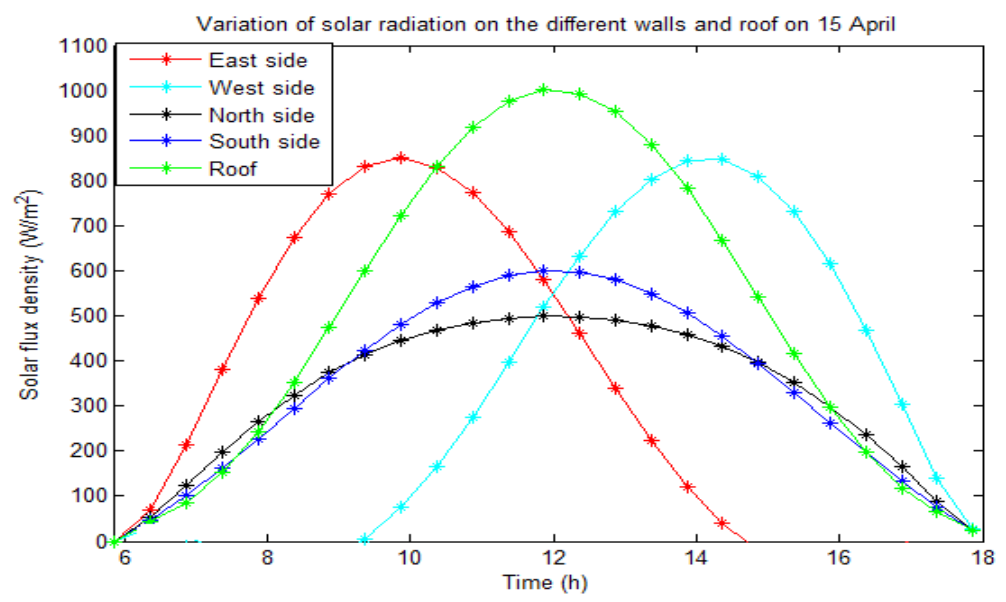

Figure 5: Variation of the solar flux on the different sides of the buildings.

From this curve in figure 5, it is noticeable that, during this period of April, the radiation received by the North face is the weakest. For this reason, we have adopted the idea to make oriented the large faces of our building in the Comsol software on the Northside because its face received the minimum of the solar heat in this period of April the warmest month of the year 2018.

These curves are obtained based on Fourier equations represented by Eq.15 and calculated using MATLAB code R2018a.

$$
P_{i}(t)=a_{0, i}+\sum_{n=1}^{4} a_{n, i} \cos \left(n w_{i} t\right)+b_{n, i} \cos \left(n w_{i} t\right)
$$




\subsection{Determination of the sensible and latent heat}

In considering that the building has no electrical appliances and non-equipped.

We need to know some values that we will have to use. They are given by[26]such as: Dry temperature [ ${ }^{\circ}$ $\mathrm{C}]=39$, Wet temperature $\left[{ }^{\circ} \mathrm{C}\right]=29.5$, and Wind speed $[\mathrm{km} / \mathrm{h}]=8.3$

Then, we calculate the sensible and latent heat of the system.

Sensible heat transfers due to transmission through the exterior walls (walls, roof, ceiling, and floor)

It acts on the contribution of the heat transmitted by the walls, the roof, the ceiling, and the floor. It is a function of the product of the temperature difference between the interior and the exterior, by the coefficient of thermal transmission of the wall or glazing and the surface [27]

$$
Q_{s t r}=K S \Delta T
$$

$\mathrm{K}$ : coefficient of thermal transmission of the wall or glazing considered in $\mathrm{W} / \mathrm{m}^{2}{ }^{\circ} \mathrm{C}$

$\mathrm{S}$ : the surface of the wall or window considered (total surface of the bay corresponding to the reservation in the wall $\left(\mathrm{m}^{2}\right), \Delta \mathrm{T}$ : temperature difference between the two faces of the wall considered $\left[{ }^{\circ} \mathrm{C}\right]$.

The sensible heat supply due to radiation through the walls

The amount of heat passing through the wall is given

$$
Q_{s r}=\alpha \cdot F \cdot S \cdot R_{\text {mes }} \cdot C_{a s} \text { (Eq.17) where, } \alpha=\text { absorption coefficient of the wall receiving the }
$$
radiation, $\mathrm{S}=$ surface of the walls in $\mathrm{m}^{2}$, the radiation factor " $\mathrm{F}$ " indicates the share of heat absorbed by the surface and transmitted through the wall of the room $=$ solar radiation factor, $\mathrm{R}_{\mathrm{mes}}=$ solar radiation absorbed on the surface of the wall in $\mathrm{W} / \mathrm{m}^{2}$.

\section{Heat supply by air renewal and infiltration}

Air renewal in an air-conditioned room is necessary for hygienic problems. It is generally done by ventilation (natural or mechanical) of the premises as well as by infiltration, introducing outside air into the air-conditioned room. It is a source of sensible and latent heat supply in the room to be conditioned.

Sensitive gains by air renewal and infiltration

$$
Q_{\text {sair }}=q_{v}\left(\theta_{e}-\theta_{i}\right) \times 0.33=400 \times(39-27) \times 0.33=1584 \mathrm{~W}
$$

\section{Latent gains by air renewal and infiltration}

$$
Q_{L}=q_{v}\left(w_{e}-w_{i}\right) \times 0.84=400 \times(0.0195-0.011) \times 0.84 \times 1000=2856 \mathrm{~W}
$$

where $\mathrm{q}_{\mathrm{v}}=$ outdoor renewal airflow [m3 / h]in this case, the ventilation is natural, we can consider that the air renewal is equal to a volume of the room per hour $(1 \mathrm{vol} / \mathrm{h})$ [27]. $\theta \mathrm{e}=$ basic outdoor temperature, $\theta \mathrm{i}=$ basic indoor temperature, $\omega \mathrm{e}=$ outdoor air water content $\mathrm{g} / \mathrm{kg}$ dry air, $\omega \mathrm{i}=$ indoor air water content $\mathrm{g} / \mathrm{kg}$ dry air.

The total energy of the system

The total thermal balance sheet $\left(\mathrm{Q}_{\mathrm{T}}\right)$ is the sum of all external and internal loads. It is more practical to sum the sensitive $\left(\mathrm{Q}_{\mathrm{S}}\right)$ and latent $\left(\mathrm{Q}_{\mathrm{L}}\right)$ charges. Hence, from where: 


$$
Q_{T}=Q_{s t r}+Q_{s r}+Q_{\text {sair }}+Q_{L}=22093.806 \mathrm{~W} \approx 22 \mathrm{~kW}
$$

These entire requirements represent the sensitive loads to be controlled to ensure an internal comfort temperature within $27^{\circ} \mathrm{C}$ in the premises.

The total amount of the cooling loads of the building is

The power of the air conditioner to install to overcome the loads and reach the comfort of $27^{\circ} \mathrm{C}$ is of the order of around $22 \mathrm{~kW}$.

$>$ Indeed, for the local not to be too wet we need to install an air conditioner that has a dehumidification power and will be of the order of $2865 \mathrm{~W}$ which is the latent heat.

This helps us to define the total cooling load and the energy-saving for each material represented in Table 3 below.

Table 3: The cooling loads and the energy conservation that can be made for each material

\begin{tabular}{|c|c|c|}
\hline & Energy-saving (KWatts) & Total of cooling loads (KWatts) \\
\hline Ambient temperature & 0 & 22,1 \\
\hline Hollow cement block & 1,76 & 20,34 \\
\hline Compressed earth block/BTC & 3,1 & 19 \\
\hline Raw earth/Adobe & 3,38 & 18,72 \\
\hline Carved lateritic block/BLT & 4,08 & 18,02 \\
\hline
\end{tabular}

During this study, we analyze the influence of the nature of the materials of the walls of the habitat, for the typical day of April. On the one hand, these habitats are built, in modern building materials (hollow cement blocks) and on the other hand, in local building materials (compressed earth blocks lateritic block and raw earth).

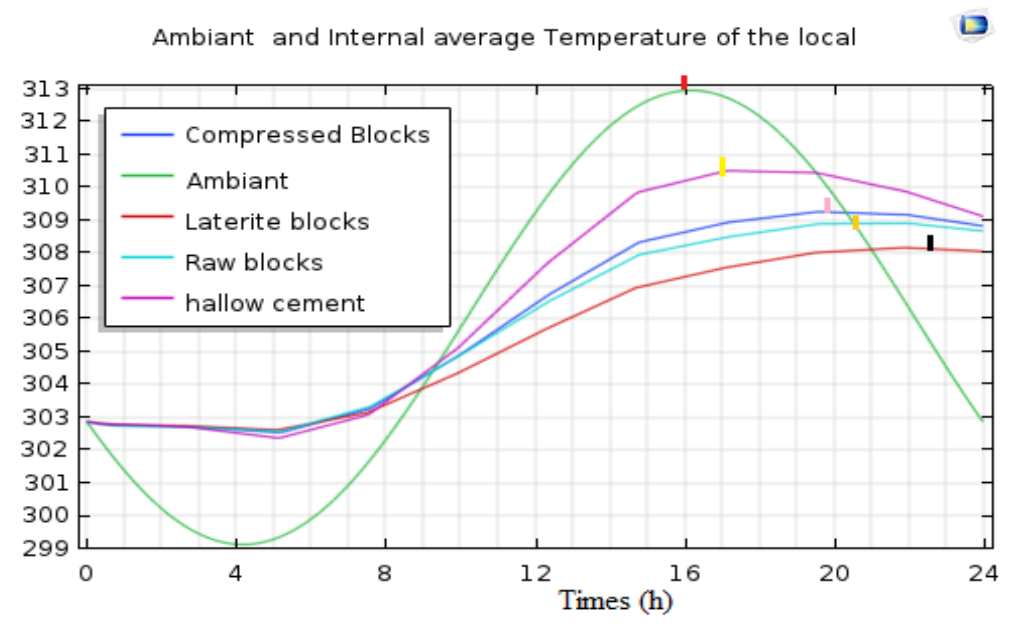

Figure 6: View of the internal average temperature for each material

In Figure 6, we can perfectly see the orders of magnitude of the internal temperature variation. 
The maximum value of the temperature reached in the cement block room is $310 \mathrm{~K}\left(37^{\circ} \mathrm{C}\right)$. They are respectively $308 \mathrm{~K}\left(35^{\circ} \mathrm{C}\right) 309 \mathrm{~K}\left(36^{\circ} \mathrm{C}\right)$ and $309.2 \mathrm{~K}\left(36.2^{\circ} \mathrm{C}\right)$, in the premises whose walls are lateritic block, raw earth, and compressed earth blocks. Our results are similar to those obtained by [28] with the same study. This result is explained by the thermal properties (density, specific heat mass, conductivity ...) of the materials. Also, the lateritic blocks and the raw earth have a high thermal inertia compared to that of the cement block. It follows that the reduction of the thermal loads of the earth constructions is greater than that of the concrete block constructions. We can, therefore, conclude that local construction materials such as raw earth or lateritic blocks have a higher thermal inertia than cement block. The result shows that; the lateritic block is the better material that we shall use to reduce the extensive use of energy of cooling purposes in our climate condition in April.

The diagram of energy-saving and cooling loads is given by the figure 12 below. We can easily see that the modern material is very energy consuming compared to the local ones. This can be explaining by the strong wall inertia of the local materials.

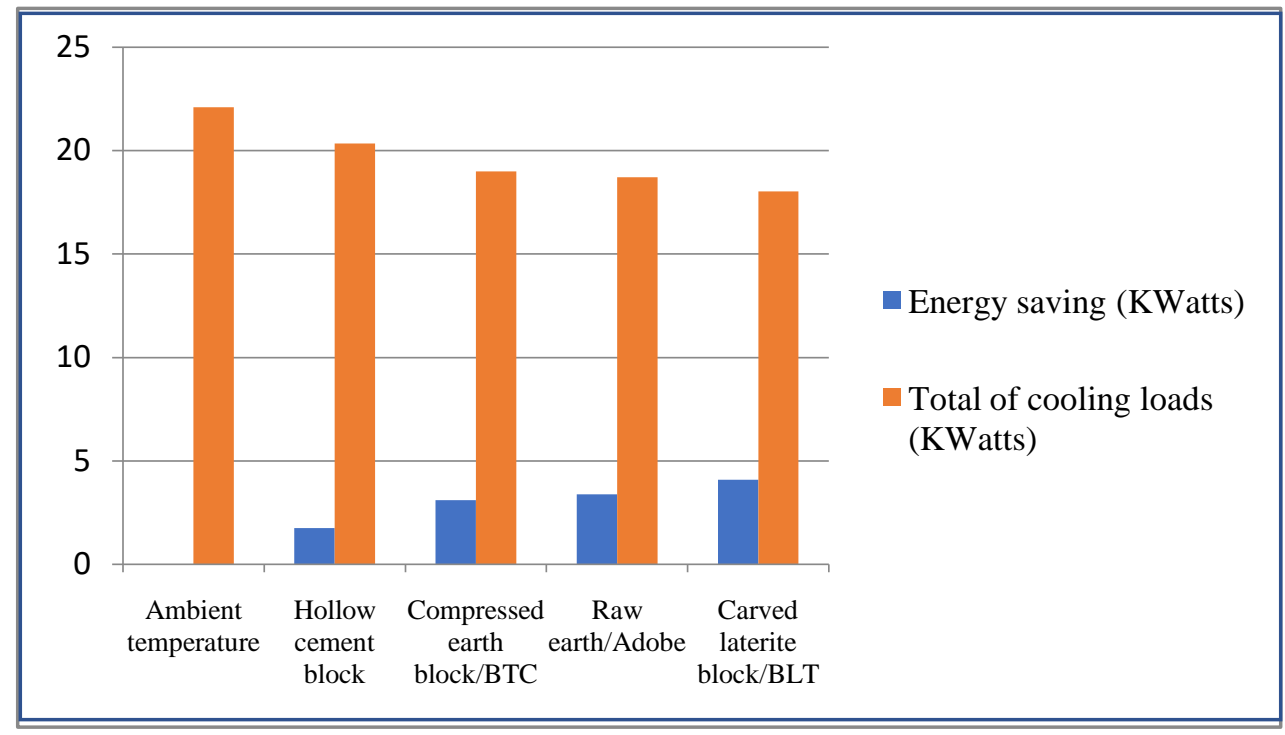

Figure 7: Histogram cooling loads of energy saving.

Figure 7 shows that around $4 \mathrm{~kW}$ can be saved if we constructed our building with carved lateritic where just $1.7 \mathrm{~kW}$ is saved with the modern Hollow cement block. The analysis of this graph shows that the significant cooling loads are significantly higher in cement block constructions compared to local materials constructions (Adobe, BTC, BLT). The construction made of BTC materials has the highest cooling loads, followed by the adobe construction. This is because BTCs are mechanically stabilized with cement so that, their thermal properties, such as conductivity, increase slightly, and that is the reason why there are slightly higher air conditioning loads in BTC habitats than in other habitats (BLT and adobe).

We should turn our mind on the use of local materials to protect the environment. The thermal insulation in buildings does not only contribute to reducing the need for air-conditioning system size but also in reducing the annual energy cost. Moreover, it helps in extending the periods of thermal comfort without reliance on mechanical air-conditioning, especially during the hot seasons. 


\section{Conclusion}

The basic model of the room was built in the standard Model Builder interface of COMSOL Multiphysics 5.3a. The study shows that among these 4 materials le BLT comes first because of the much energy saving that can be made in its room because it has strong wall inertia. This study shows that around $4 \mathrm{~kW}$ can be saved if we constructed our building with carved lateritic where just $1.7 \mathrm{~kW}$ is saved with the modern Hollow cement block. We should turn our mind on the use of local materials to protect the environment. Based on the result of the analysis we can perfectly say that the use of local materials is an alternative way to reduce the energy demand in building. As a perspective, we will try to use the solar cooling system to improve comfort instead of compressor vapor based on ecological issues and protection of the ozone layer. These compressors systems have impacts on stratospheric ozone depletion because of the chlorofluorocarbons (CFC) and the hydro fluorocarbon (HCFC) refrigerants. Solar is clean and abundant. It can help to reduce the electricity peak as maximum solar radiation usually occurs when cooling is needed so that, solar-powered cooling systems as a green cold production technology are the best alternative.

\section{Acknowledgments}

The ISP, Uppsala University, Sweden is gratefully acknowledged for its support to the project BUF01.

\section{References}

[1]. IPCC, "GIEC: synthesis Reports. Contribution of Working Groups to the Fourth Assessment Report of the Intergovernmental Panel on Climate Change, Genève," 2009.

[2]. A. Allouhi, T. Kousksou, A. Jamil, P. Bruel, Y. Mourad, and Y. Zeraouli, "Solar driven cooling systems: An updated review," Renew. Sustain. Energy Rev., vol. 44, pp. 159-181, 2015.

[3]. W. Zhang, F. Liu, and R. Fan, "Improved thermal comfort modeling for smart buildings: A data analytics study," Int. J. Electr. Power Energy Syst., vol. 103, no. February, pp. 634-643, 2018.

[4]. M. S. Al-Homoud, "Performance characteristics and practical applications of common building thermal insulation materials," Build. Environ., vol. 40, no. 3, pp. 353-366, 2005.

[5]. F. Farmani, M. Parvizimosaed, H. Monsef, and A. Rahimi-kian, "Electrical Power and Energy Systems A conceptual model of a smart energy management system for a residential building equipped with CCHP system," Int. J. Electr. Power Energy Syst., vol. 95, pp. 523-536, 2018.

[6]. V. Vakiloroaya, B. Samali, A. Fakhar, and K. Pishghadam, "A review of different strategies for HVAC energy saving," Energy Convers. Manag., vol. 77, pp. 738-754, 2014.

[7]. P. Hameed, N. Bin, M. Nor, P. Nallagownden, I. Elamvazuthi, and T. Ibrahim, "Intelligent multi-objective control and management for smart energy efficient buildings," Int. J. Electr. Power Energy Syst., vol. 74, pp. 403-409, 2016.

[8]. P. Höppe, "Different aspects of assessing indoor and outdoor thermal comfort," Energy Build., vol. 34, no. 6, pp. 661$665,2002$.

[9]. R. J. De Dear et al., "Progress in thermal comfort research over the last twenty years," Indoor Air, vol. 23, no. 6, pp. 442-461, 2013.

[10].A. Compaore, Etude Des Performances Thermiques D'un Habitat Type Du Burkina Faso. Application : Contribution A La Mise En Place D'une Reglementation Thermique, 'Université Ouaga I Professeur JOSEPH KI-ZERBO, 2018.

[11].P. Hameed, N. Bin, M. Nor, P. Nallagownden, I. Elamvazuthi, and T. Ibrahim, "Intelligent multi-objective control and management for smart energy efficient buildings," Int. J. Electr. POWER ENERGY Syst., vol. 74, pp. 403-409, 2016.

[12].B. Paris et al., "Hybrid PID-fuzzy control scheme for managing energy resources in buildings To cite this version : HAL Id : hal-00628879," 2011.

[13].J. C. Damfeu, P. Meukam, Y. Jannot, and E. Wati, "Modelling and experimental determination of thermal properties of local wet building materials," Energy Build., 2016.

[14].L. Mohamed, K. Mohamed, L. Najma, and K. Abdelhamid, "Thermal characterization of a new effective building material based on clay and olive waste," vol. 02053, pp. 1-6, 2018.

[15].D. TOGUEYENI, O. COULIBALY, A. OUEDRAGO, D. R. Rousse, and Yvan, "Étude De L'influence De Materiaux Locaux Isolants De Toiture Sur Les Charges De Climatisation D’une Maison Individuelle En Argile-Paille 2012 - art13-93," Cifem2, pp. 13-93, 2012.

[16].B. Moujalled, "Modélisation dynamique du confort thermique dans les bâtiments naturellement ventilés," 'Institut des Sciences Appliquées de Lyon, 2007.

[17].R. Cantin, B. Moujalled, and G. Guarracino, "Complexité du confort thermique dans les bâtiments," 6ème congrès Eur. Sci. des Systèmes Paris, pp. 1-10, 2005.

[18]."Ministère de l'Energie et des Mines du Burkina Faso., 'Direction Générale de l'Energie, Audit Energétique et Stratégie 
Energétique Domestiques (SED), , 2003.

[19].P. O. Fanger, “ Thermal Comfort, Analysis and Applications in Environmental Engineering,” New York. 1972.

[20].F. Nicol, "Adaptive thermal comfort standards in the hot-humid tropics," Energy Build., vol. 36, no. 7, pp. 628-637, 2004.

[21].C. Art--, D. A. C. Cotonou-benin, A. Olissan, C. Kouchade, P. Andre, and C. N. Awanou, "Cifem2012 - art-13-53," no. 1960, pp. 1-6, 2012.

[22].A. O. Fati, B. A. Latif, O. Souleymane, S. M. K. Thierry, M. Lewamy, and B. D. Joseph, “The Impact of Local Materials on the Improvement of the Thermal Comfort in Building," vol. 39, no. 15, pp. 22-35, 2020.

[23].V. Gerlich, "Modelling of heat transfer in buildings," Proc. - 25th Eur. Conf. Model. Simulation, ECMS 2011, pp. 244248, 2011.

[24].I. de l'Energie et de l'Environnement de la F. (IEPF), Efficacite energetique de la climatisation en region tropicale Tome1: Conception des nouveaux bâtiments. 2001.

[25].H. Charvátová and A. Procházka, "Computer Simulation of Temperature Distribution,” pp. 1-16, 2018.

[26].ADEREE, "Les éléments techniques du projet de la réglementation thermique du bâtiment au Maroc," p. $34,2011$.

[27].B. Vondou, "Analyse des differentes methodes de bilan thermique en climatisation," De Douala, 2018.

[28].D. J. B. Abdoulaye COMPAORE , Boukaré OUEDRAOGO, Hassime GUENGANE, Etienne MALBILA, "Role of Local Building Materials on the Energy Behaviour of Habitats in Ouagadougou," IRA Int. J. Appl. Sci., no. August, pp. 63-72, 2017. 